\title{
Diffüz idiyopatik iskelet hiperostozlu bir hastada minör travma ile gelişen subakut torakal omurilik yaralanması
}

\author{
Subacute thoracic spinal cord injury caused by minor trauma in a patient with diffuse \\ idiopathic skeletal hyperostosis

Şükran Güzel Ajda Bal İbrahim Gündoğdu Deniz Erdoğdu Aytül Çakcı \\ Dışkapı Yıldııım Beyazıt Eğitim Araştırma Hastanesi, Fiziksel Tıp ve Rehabilitasyon Kliniği, Ankara, \\ Türkiye
}

\section{Öz}

Ankiloze omurgalar, değişen biyomekanik özelliklerinden dolayı minör travma sonrasında bile kırılma eğilimi gösterebilirler. Ankilozlu omurgadaki kırıklar, yumuşak dokuların ossifikasyonu nedeniyle genellikle instabildir ve dislokasyona neden olarak nörolojik defisit oluşturabilir. Diffüz idiyopatik iskelet hiperostozu (DISH); ileri yaşta ve erkeklerde daha sık görülen, etiyolojisi tam olarak bilinmeyen, sıklıkla vertebral kolonun anterior longitudinal ligamenti ve entezis bölgelerinde ossifikasyon ile karakterize, sistemik, noninflamatuvar bir iskelet hastalığıdır. Ossifikasyon omurganın mobilitesini azaltmakta ve ileri dönemde ankiloza yol açabilmektedir. Bu yazıda minör travma sonrası akut dönemde tanı almamış, subakut dönemde omurga fraktürü ve spinal kord yaralanması gelişmiş bir DISH olgusunun literatür eşliğinde sunulması amaçlanmaktadır.

Anahtar Sözcükler: Diffüz idiyopatik iskelet hiperostozisi, omurilik yaralanmaları, omurga kırıkları.

\begin{abstract}
The ankylosed spines are prone to fracture after minor trauma due to its changed biomechanical properties. Fractures in the ankylosed spine are often unstable due to the ossification of supportive and elastic soft tissues and may cause neurologic deficit as a result of dislocation. Diffuse idiopathic skeletal hyperostosis (DISH) is a systemic, noninflammatory skeletal disease characterized by ossification in the anterior longitudinal ligament of the vertebral column and entheses, which is more common in elderly and males and whose etiology is not known. Ossification reduces the mobility of the spinal cord and may lead to ankylosis in the future. In this article, we present case of DISH which has not been diagnosed in acute period after minor trauma and has developed spinal fracture and spinal cord injury in subacute period.
\end{abstract}

Keywords: Diffuse idiopathic skeletal hyperostosis, spinal cord injuries, spinal fractures.

\section{Giriş}

Ankiloze omurgalar, değişen biyomekanik özelliklerinden dolayı minör travma sonrasında bile kırılma eğilimi gösterebilirler. Ankilozlu omurgadaki kırıklar, yumuşak dokuların ossifikasyonu nedeniyle genellikle instabildir ve dislokasyona neden olarak nörolojik defisit oluşturabilir.

Diffüz idiyopatik iskelet hiperostozu (DISH), yaşlı ve erkeklerde daha sık görülen, etiyolojisi tam olarak bilinmeyen, sıklıkla vertebral kolonun anterior longitudinal ligamenti ve entezis bölgelerinde ossifikasyon ile karakterize, sistemik, noninflamatuvar bir iskelet hastalığıdır.

\footnotetext{
Yazışma Adresi: Şükran Güzel

Dışkapı Yıldırım Beyazıt Eğitim Araştırma Hastanesi Fiziksel Tıp ve Rehabilitasyon Kliniği Ankara-Türkiye

Makalenin Geliş Tarihi: 28.09.2017 Kabul Tarihi: 20.11.2017
}

Ossifikasyon omurganın mobilitesini azaltmakta ve ileri dönemde ankiloza yol açabilmektedir. DISH'li hastaların birçoğu asemptomatik olmakla birlikte en sık görülen belirtiler omurgada ağrı ve hareket kısıtılığıdır. DISH'in önemli komplikasyonları; disfaji, zorlu endotrakeal entübasyon, miyelopati ve spinal stenozdur. Nörolojik bulgular nadir görülmektedir, bu bulgular posterior longitidunal ligaman ve ligamentum flavum ossifikasyonu nedeniyledir (1).

Burada minör travma sonrası akut dönemde tanı almamış, subakut dönemde omurga fraktürü ve spinal kord yaralanması gelişmiş bir DISH olgusu sunulmaktadır.

\section{Olgu Sunumu}

75 yaşında erkek hasta merdivenin son iki basamağından düşme sonrası dış merkezde acil servise başvurmuş. Fizik muayenede ve torakolomber vertebral 
bilgisayarlı tomografide (BT) fraktür lehine bir bulgu saptanmayan hasta taburcu edilmiş. Düşmeden bir ay sonra bilateral alt ekstremitesinde ani gelişen güçsüzlük şikayeti ile dış merkezde beyin cerrahisi polikliniğine başvurmuş. Yeni çekilen torakolomber vertebral BT'de T3 vertebra korpusu anterior bölümünde belirgin yükseklik kaybı ile birlikte bu düzeyde anteriora kifotik açılanma ve torakal vertebraların korpus anterior bölümlerinde ileri derecede, çoğu bölümde köprüleşmeye varan sindesmofitler belirlenmiş. Torakolomber manyetik rezonans görüntülemesinde (MRG) ise vertebralarda dejeneratif osteofitik değişiklikler, spur formasyonları izlenmiş. T2 ağırlıklı sagital kesitte T3 vertebrada transvers lineer hiperintensite görülmüş. T3-T4 vertebralarda ödematöz sinyal değişiklikleri ve yükseklik kaybı olduğu gözlenmiş (Şekil-1).

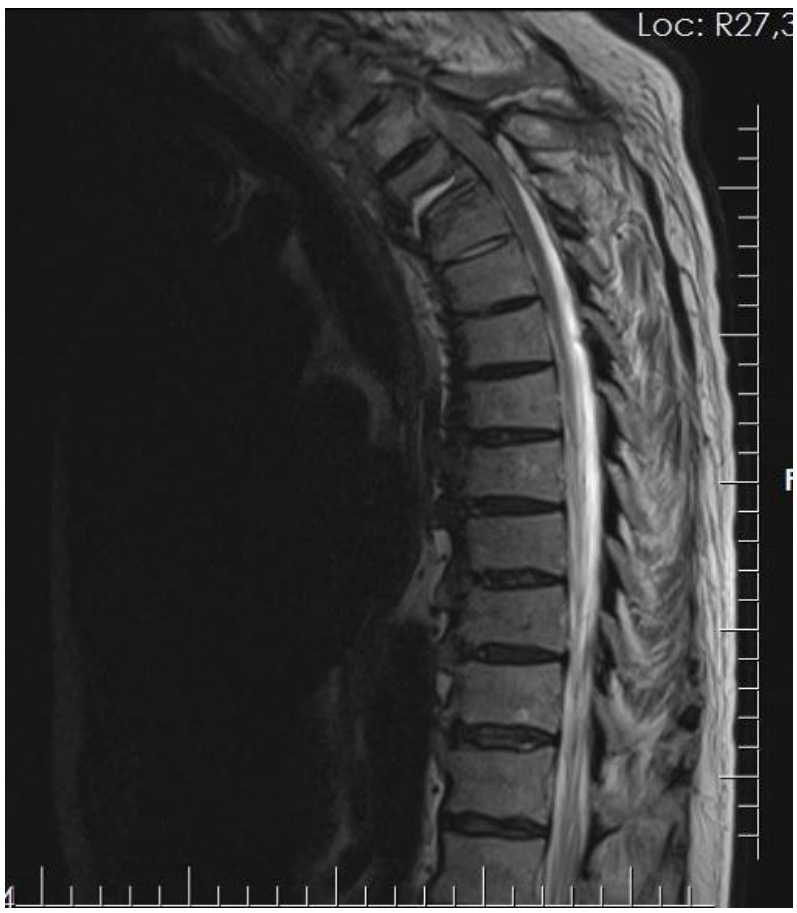

Şekil-1. Torakolomber MRG'de T2 ağırlıklı sagital kesitte T3 vertebrada transvers lineer hiperintensite, T3-T4 vertebralarda ödematöz sinyal değişiklikleri ve yükseklik kaybı, spinal kordda aynı seviyede hafif hiperintensite izlenmektedir.

Yağ baskılı T1 ağırlıklı görüntülerde sagital kesitte spinal kordda aynı seviyede hafif hiperintensite olduğu görülmüş. Faset eklemlerde hipertrofi ve posterior longitudinal ligaman ossifikasyonu saptanmamış. Bu sonuçlar ile hasta hastanemizin beyin cerrahi servisine sevk edilmiş ancak endotrakeal entübasyon riski olduğu için opere edilmemiş ve antiödem tedavisine başlanılmış. Tedavi sonrası servisimize rehabilitasyon amacı ile nakil alınan hastanın özgeçmiş sorgulamasında hipertansiyon ve kür mesane kanseri öyküsü mevcuttu. Hastanın sistemik sorgulamasında psöriazis, üveit, inflamatuvar barsak hastalığı ve ailede romatizmal hastalık öyküsü mevcut değildi. Fizik muayenesinde servikal omurga eklem hareket açıklıkları (EHA) tüm yönlerde tama yakın kısıtlıydı. Lomber omurga EHA fleksiyonun son $2 / 3$ kısmı ve ekstansiyon tama yakın kısıtlıydı. Üst ekstremite tüm kas grupları 5/5 ve alt ekstremite tüm kas grupları $2 / 5$ kuvvetindeydi. Hafif dokunma duyusu bilateral L4 dermatomu ve altında, pinprick testi ise T1 dermatomu ve altında S4-5'i kapsayacak şekilde hipoestezik idi. İstemli anal kontraksiyonu mevcuttu. Hastanın idrar ve gaita inkontinansı yoktu. Hasta, American Spinal Cord Injury Association (ASIA) bozukluk skalasına göre inkomplet C grubunda idi. Motor ve duyu seviyesi C8 olarak değerlendirildi. Fonksiyonel Bağımsızlık Ölçeği (FBÖ) skoru 46 idi. Hastanın vertebral fraktürü olması nedeni ile Kemik Mineral Yoğunluğu (KMY) ölçümü istendi. Femur boyun T skoru: 0.7; L1-L4 total T skoru:5.1 olarak rapor edildi. Torakal ve lomber omurgada iki yönlü grafisinde yaygın osteopeni, hemen tüm seviyelerde akan ve köprüleşen sindesmofitler mevcuttu.

Öyküsü, fizik muayenesi ve radyografik değerlendirmeleri sonucu DISH tanısı konuldu. Düşük enerjili travmaya bağlı gelişen vertebral fraktürün ise omurgadaki rijidite nedeniyle geliştiği düşünüldü. Spinal kord yaralanması ise fraktüre bağlı gelişen ödem ve iskemi ile ilişkilendirildi.

Hastadan tıbbi verilerinin yayınlanabileceğine ilişkin yazılı onam belgesi alındı.

\section{Tartışma}

Ankiloze omurga; minör travmadan sonra bile fraktür riski taşımaktadır ve nörolojik defisite neden olabilmektedir. Bazı çalışmalarda, omurgada ankiloza yol açan bir başka hastalık olan ankilozan spondilit (AS) tanılı hastaların normal bireylere kıyasla yaşam boyu dört kat daha fazla kırık riskine sahip olduğu gösterilmiştir. Bu durumun nedeni olarak AS'ye sekonder olarak gelişen osteoporoz, rijit omurganın travma enerjisini çevre yumuşak dokulara dağıtamaması ve uzun bir kaldıraç kolu gibi davranıp omurgada yoğun bir bükülme kuvveti oluşturması sorumlu tutulmaktadır.

Daha az sıklıkta olmakla birlikte DISH'li hastalarda da; AS'de görüldüğü gibi spinal mobilitede ciddi limitasyon ve postürel anormallik görülebilmektedir. DISH'li hastaların da AS'li hastalarda olduğu gibi minör travma sonrası omurga fraktürleri açısından risk altında olduklarını düşünülmektedir (2).

DISH sıklıkla asemptomatik olup ve insidental olarak tanı konulmaktadır. Ayırıcı tanısında AS, reaktif artrit ve psöriatik artrit bulunmaktadır. DISH'te sindesmofitler abartılı, geniş, düzensiz ve akar tarzda olup en kalın disk aralığı seviyesinde ve omurga gövdesine komşu olan bölgelerdedir. DISH'te AS'nin aksine disk aralığı daralmaz, apofizyel, kostovertebral ve sakroiliak eklemler korunur (3). Olgumuz sindesmofit özellikleri, 
disk aralıklarının korunmuş olması sakroiliak eklemlerde ve faset eklemlerde füzyon olmaması nedenleriyle DISH ile uyumluydu.

Osteoporoza DISH'te AS'ye göre daha az sıklıkla rastlanır. AS'de spinal fraktürler osteoporoz olması nedeni ile DISH'e göre daha sık görülmektedir (4). Olgumuzda direkt radyografide vertebral osteopeni görülmesine rağmen $\mathrm{KMY}$ ölçümünde osteoporoz saptanmamasının DISH'e bağlı ossifikasyonlar nedeniyle olduğu düşünüldü.

DiSH ve AS hastalarında omurilik kırıklarının farklı paternleri, bu hastalıkların patomekanizmasındaki farklılıklar ile açıklanabilir. DISH'te vertebral gövdedeki kırıklar intervertebral diske düzeyinde olan kırıklardan daha sık görülürken AS'de bu durum tam tersidir (5). Hastamızın vertebral kırık özellikleri de literatür bilgisiyle uyumluydu.

Ankiloze omurgada gelişen fraktürlerin büyük çoğunluğu düşük enerjili travma ile gelişir ve genellikle servikal omurgadadır (6). Olgumuzda farklı olarak torakal vertebra fraktürü mevcut idi. Ankiloze omurgalı hastalarda vertebral fraktürler erken dönemde gözden kaçırılabilir. DISH'e bağlı mekanik spinal ağrı ile fraktüre bağıı gelişen ağrıyı ayırt etmesi zor olabilir. Ayrıca ankiloze omurganın radyografik görüntüsü de fraktürün görülmesini zorlaştırabilmektedir (7). Literatürdeki bazı vakalarda, AS hastalarında ani nörolojik defisit ortaya
Çıkıncaya kadar fraktür saptanmamıştır (8). Corke (9) tarafından yapılan bir vaka sunumunda DISH tanısı olan hastada, minör travma sonrası nörolojik muayenede ve radyografide patoloji saptanmayıp ilerleyen dönemde gelişen parapleji tablosu üzerine tekrar yapılan görüntülemelerde instabil lomber fraktür saptanmıştır.

Hendrix ve ark. (7) yaptığı vaka serisinde 15 spinal fraktürü olan DISH tanılı hastanın 12'sinde servikal, birinde torakal, birinde lomber fraktür mevcuttu. Bu hastaların 11'inde minör travma sonucunda fraktür gelişmişti. Hastalardan 9'unda komplet, 3'ünde inkomplet spinal kord yaralanması görülmüştü. Üç hastada ise travma sonrası akut dönemde nörolojik ve radyolojik patoloji saptanmamış olup daha sonra bu 3 hastanın 2'sinde nörolojik defisit gelişmesi üzerine fraktür tanısı almıştır. Olgumuzda da subakut dönemde gelişen nörolojik defisit sonrası vertebral fraktür saptanmıştır.

Olgumuz daha önce tanı almamış, minör travma sonrasında erken dönemde vertebral fraktür saptanamamış, subakut dönemde parapleji gelişimi sonrasında tanı almış olması nedeni ile sıra dışıdır. DISH hastalarında minör travma sonrasında da spinal kord hasarı meydana gelebileceği dikkate alınmalı ilk değerlendirmede kırık saptanmasa bile hasta olası fraktür açısından takibe alınmalıdır.

\section{Kaynaklar}

1. Kurtaran A, Özdemir S, Selçuk B, Yıldırım Ö, Değirmenci İ, Akyüz M. Servikal bölgedeki yaygın idiopatik iskelet hiperostozuna bağlı gelişen santral kord sendromu. Türkiye Fiziksel Tıp ve Rehabilitasyon Dergisi 2012;58(4):326-8.

2. Belanger TA, Rowe DE. Diffuse idiopathic skeletal hyperostosis: Musculoskeletal manifestations. J Am Acad Orthop Surg 2001;9(4):258-67.

3. Resnick D. Diffuse idiopathic skeletal hyperostosis. In: Resnick D (ed). Diagnosis of Bone and Joint Disorders. $4^{\text {th }}$ ed., Philadelphia; Saunders; 2002;1476-1503.

4. Wang YF, Teng MM, Chang CY, Wu HT, Wang ST. Imaging manifestations of spinal fractures in ankylosing spondylitis. Am J Neuroradiol 2005;26(8):2067-76.

5. Graham B, Van Peteghem PK. Fractures of the spine in ankylosing spondylitis. Diagnosis, treatment, and complications. Spine 1989;14(8):803-7.

6. Secin FP, Poggi EJT, Luzuriaga F, Laffaye HA. Disabling injuries of the cervical spine in Argentine rugby over the last 20 years. Br J Sports Med 1999;33(1):33-6.

7. Hendrix RW, Melany M, Miller F, Rogers LF. Fracture of the spine in patients with ankylosis due to diffuse skeletal hyperostosis: Clinical and imaging findings. Am J Roentgenol 1994;162 (4):899-904.

8. Schroder J, Liljenqvist U, Greiner C, Wassmann H. Complications of halo treatment for cervical spine injuries in patients with ankylosing spondylitis--report of three cases. Arch Orthop Trauma Surg 2003;123(2-3):112-4.

9. Corke CF. Spinal fracture and paraplegia after minimal trauma in a patient with ankylosing vertebral hyperostosis. $\mathrm{Br}$ Med $\mathrm{J}$ $1981 ; 282(6281): 2035$. 